\title{
ENERGY LOSSES WITHIN THE ELECTRIC EQUIPMENT IN TERMS OF POOR VOLTAGE QUALITY
}

Yu. Papaika, O. Lysenko, M. Rogoza, Yu. Stepanenko, L. Tokar

National Technical University Dnipro Polytechnic

prosp. Dmytro Yavornytsky, 19, Dnipro, 49005, Ukraine.

E-mail: papaika@ukr.net; lysenkoag@ukr.net; rogozam@nmu.org.ua; yuvist@ukr.net; 1rstokar@gmail.com

\section{S. Yakimets}

Kremenchuk Mykhailo Ostrohradskyi National University

vul. Pershotravneva, 20, Kremenchuk, 39600, Ukraine. E-mail: ysm_seem@meta.ua

Purpose. Determining the economically feasible level to which the quality of the electricity should be improved is a key to the adequate calculation of the economic loss due to electricity supply of lower quality electricity. In the studies, the electromagnetic and technological components of the economic damage caused by the reduced quality of electric power are considered.The paper is aimed at the integration of such notionsas energy-efficiency and energy-supply quality. Methodology. Modern methods to determine additional power losses within the basic electric equipment and losses due to poor energy supply have been demonstrated. Methods of estimation of the electromagnetic and technological component of economic damage caused by the reduced quality of electric power in electric networks of industrial enterprises are considered. Results. Dependences of power losses in asynchronous motors, capacitor units, and power transformers have been obtained with the application of scientifically substantiated term "remoteness" being a remoteness of the source of electromagnetic interferences within the electrical network. It is stated that the main reasons for the decrease of voltage quality in electric networks of Ukraine are mass implementation of frequency converters and poor quality control of energy from energy companies. Practical value. The research results make it possible to evaluate the efficiency of electric supply under conditions of constant changes in parameters and uncertainty that is the basis to develop so-called "intellectual" electric supply. The developed models will be based on a comprehensive methodology for determining optimal power supply. The methodology can be applied for power supply systems of cities, enterprises and power associations. Originality. The originality of the work is to substantiate the notion of the relative distance of electrical equipment from the point of the generation of electromagnetic interference and deduces the dependence which connects the introduced term with the depth of communication distortions and viscous harmonic components.

Key words: electric power quality, power losses, power transformers, asynchronous motors, condenser units, electrical power networks.

\section{ВТРАТИ ЕНЕРГІЇ В ЕЛЕКТРООБЛАДНАННІ ПРИ НИЗЬКІЙ ЯКОСТІ НАПРУГИ}

\section{Ю. А. Папаїка, О. Г. Лисенко, М. В. Рогоза, Ю. В. Степаненко, Л. О. Токар}

Національний технічний університет «Дніпровська політехніка»

просп. Дмитра Яворницького, 19, м. Дніпро, 49005, Україна.

E-mail: papaika@ukr.net; lysenkoag@ukr.net; rogozam@nmu.org.ua; yuvist@ukr.net; lrstokar@gmail.com

\section{С. М. Якимець}

Кременчуцький національний університет імені Михайла Остроградського

вул. Першотравнева, 20, м. Кременчук, 39600, Україна. E-mail: ysm_seem@meta.ua

Визначення економічно доцільного рівня, до якого слід покращувати якість електроенергії, є запорукою адекватного розрахунку економічного збитку внаслідок електропостачання електроенергії зниженої якості. Дана публікація спрямована на об’єднання термінів енергоефективність та якість електропостачання. Розглянуто електромагнітну та технологічну складові економічного збитку, обумовленого зниженою якістю електроенергії. Показано сучасні методи визначення додаткових втрат потужності в основному електрообладнанні та збитків від постачання неякісної електроенергії. Вказано, що основні причини зниження якості напруги в електричних мережах України - це масове впровадження перетворювачів частоти та незадовільний контролю за якістю енергії з боку енергетичних компаній. Отримано залежності втрат потужності у асинхронних двигунах, конденсаторних установках та силових трансформаторів із застосуванням науково обгрунтованого терміну «віддаленість» джерела електромагнітних завад у електричній мережі. Результати дослідження дозволяють оцінювати ефективність електропостачання в умовах постійної зміни параметрів та невизначеності, що є основою створення так званого «інтелектуального» електропостачання. Розроблені моделі будуть покладені в основу комплексної методики визначення оптимального електропостачання. Методика може бути застосована для систем електропостачання міст, підприємств та електроенергетичних об'єднань. Оригінальність роботи полягає у обгрунтуванні поняття відносної віддаленості електрообладнання від точки геренерації електромагнітної перешкоди та виведено залежність, яка пов'язує введений термін з глибиною комунікаційних викривлень і високими гармонійними складовими.

Ключові слова: якість електричної енергії, втрати електроенергії, силові трансформатори, асинхронні двигуни, конденсаторні установки, електричні мережі.

PROBLEM STATEMENT. Adequacy of the selection of methods and facilities to improve electric energy quality as well as to determine economically expedient level of electric energy quality should be determined involving the calculation of possible economic losses due to poor quality of the electric energy. It is also re- 
quired to evaluate losses while settling conflicts, caused by insufficient electric energy quality, between energysupplying enterprises and energy consumers. According to the studies, economic losses stipulated by the decreased quality of electric energy have two constituent parts: electromagnetic and technological [1-3]. Electromagnetic one is caused by certain changes in active power losses and the corresponding service life of electric equipment insulation. In this context, losses connected with the unsinusoidality, asymmetry, and voltage oscillations will be equal to zero in terms of sinusoidality and symmetry of phase-to-phase voltage systems and non availability of oscillations. Technological constituent of the losses is stipulated by the effect of voltage quality upon the productivity of processing plants and prime cost of the products. Development of scientific foundations to determine efficiency criteria for energy systems operation in terms of fuzzy reliability and energy-supply quality is a rather topical problem to be solved.

MATERIAL AND RESULTS. Further, methods to evaluate electromagnetic and technological constituents of economic losses stipulated by the decreased quality of electric energy within the electric networks of enterprises are considered [1-3].

Additional losses due to low-quality electric energy result in additional heating $\Delta \tau$ of electric equipment and reduced service life of insulation (and all the electric equipment in general) by value $T_{c}=T_{c}-T_{c}^{A E}$ where $T_{c}$ and $T_{c}^{A E}$ are service life of the elements of an electric-supply system (ESS) in terms of high-quality and low-quality electric energy $[1,2]$.

"Lifetime" of insulation:

$$
T_{c}=A e^{-\alpha \Delta \tau},
$$

where $A-$ is coefficient depending upon the insulation type; $\alpha-$ is coefficient of insulation ageing determined as:

$$
\alpha=\frac{\ln 2}{\Delta \tau} .
$$

If insulation is of $A$ class, then: $\alpha=0,086$ $\left(\Delta \tau=8^{\circ}\right)$; in case of class $B$, we have: $\alpha=0,693$ $\left(\Delta \tau=10^{\circ}\right)$.

While solving problems of electromagnetic compatibility in Ukraine and CIS countries, so-called "eightdegree" rule is applied: $\alpha=0,086$; in this context, relative reduction of insulation service life is

$$
\Delta t^{*}=T_{c}-\frac{T_{c}^{A E}}{T_{c}}=0,086 \Delta \tau+\frac{(0,086 \Delta \tau)^{2}}{2} .
$$

Expressions to evaluate electromagnetic losses [1-3] and $\Delta t$ in terms of the available higher harmonics and asymmetry as well as the expressions to assess losses assuming that electric machines are considered as single physical bodies are represented below.

Electromagnetic component in terms of voltage unsinusoidality is determined by: increase in active power losses, growth in the consumed active and reactive power; accelerated ageing of electric equipment insulation; limited sphere of capacitors application to increase power factor [2, 4-6].

In terms of the specified operating mode of the elements, additional losses of active power [1-3] stipulated by voltage unsinusoidality are determined according to expression

$$
\Delta P_{n}=\frac{\Delta P_{n o m}}{\left(z_{1}^{*}\right)^{2}} \sum_{n=2}^{\infty} \frac{\left(U_{n}^{*}\right)^{2}}{n \sqrt{n}},
$$

here $\Delta P_{n o m}-$ is a nominal loss of active power in conductive parts of electric equipment, $\mathrm{kW} ; z_{1}^{*}=\frac{z_{1}}{z_{\text {nom }}}-$ is relative complex impedance of the element to the circuit current of basic frequency; $U_{n}^{*}=\frac{U_{n}}{U_{n o m}}-$ is relative value of voltage harmonic of $n^{\text {th }}$ order; $n-$ is number of voltage harmonics being taken into consideration.

Additional losses in electric motors are proportional to value:

$$
\sum_{n=2}^{n} \frac{U_{n x}}{n \sqrt{n}}=\sum_{n=2}^{n} \Lambda_{n} U_{n x}^{2},
$$

where $\Lambda_{n}=\frac{1}{n \sqrt{n}}$ is coefficient of harmonic losses.

Value of coefficient $\Lambda_{n}$ is represented in specialized literature; the value depends upon the harmonic number [2].

Expression to evaluate losses in terms of $\mathrm{HH}$ frequencies is as follows:

$$
\Delta P_{n}=\Delta P_{n o m} \rho_{H G} \sum_{n=2}^{n} \Delta_{n} U_{n x}^{2},
$$

where $\rho_{H G}-$ is index of losses for higher harmonics: for asynchronous motor (AM): $\rho_{H G}^{A M}=K_{S}^{2}$, where $K_{S}$ is starting current ratio.

When higher current harmonics pass through the element of electric-supply system (motors, transformers, capacitors, cables etc.), there is the acceleration in insulation ageing due to the effect of both additional heating of conductive parts and dielectric heating under the influence of high-frequency electromagnetic fields. Relative (as for the sinusoidal current mode) reduction of insulation service life $\Delta t_{n}^{*}$ is determined as:

$$
\Delta t_{n}^{*}=\left\{\begin{array}{l}
0,087 \tau_{1}-\text { for insulation of } A, E \text { class; } \\
0,069 \tau_{1}-\text { for insulation of } B, F \text { class. }
\end{array}\right.
$$

While calculating losses due to additional thermal ageing of insulation, relative reduction in its service life is determined by relative increase in deductions $\Delta C_{p}^{*}$ for renovation of electric equipment: $\Delta t_{n}^{*}=\Delta C_{p}^{*}$ [2].

Annual loss (UAH/year) caused by additional losses of active power and additional thermal ageing of electric equipment insulation is calculated according to following expression:

$$
Y_{n}^{(\Delta P)}=\beta T^{(s)} \Delta P_{n}^{(3)} \cdot 10^{3}+\Delta C_{p}^{*(s)} C_{p}^{*(s)} K^{(s)},
$$


where $\beta$-is cost of $1 \mathrm{~kW} \cdot$ hour of electric energy losses, $\mathrm{UAH} / \mathrm{kW} \cdot$ year; $T^{(s)}$ - is period of service life of $S^{\text {th }}$ type of electric equipment per year, thousand hours; $C_{p}^{*(s)}$ - is standardized coefficient of deductions for renovation from capital costs $K^{(s)}$ of $S^{\text {th }}$ type of electric equipment.

While calculating losses in cables and capacitors, costs of additional electric power losses in them may be neglected $[1,2,4]$.

Electromagnetic component in terms of voltage asymmetry is determined by: increase in active power losses; identification of ageing process in electric equipment insulation; insufficient generation of reactive power by capacitors and synchronous machines; necessity to overestimate nominal power of electric motors and transformers as well as cross-sections of cables and wires; decrease in the efficiency of working surface lighting and decrease in service life of lighting instruments.

Additional power losses $\Delta P_{N S}$ stipulated by voltages asymmetry in terms of stable operating mode of the energy-supply system elements are determined as follows [2]:

$$
\Delta P_{N S}=\frac{U_{n o m}^{2} r_{2}}{z_{2}^{2}} K_{2 U}^{2},
$$

where $r_{2}$ and $z_{2}$ - a reactive and complex impedance of the energy-supply system element to negativesequence current.

Or

$$
\Delta P_{N S}=\Delta P_{n o m} \rho^{(N S)} K_{2}^{2 U}
$$

where $K_{2 U}$ is coefficient of asymmetry, r.u.

Interms of $A M$ :

$$
\rho_{A M}^{(N S)}=2,41 K_{s},
$$

where $K_{s}$ is starting current ratio.

In terms of synchronous motors (SM):

$$
\rho_{S M}^{(N S)}=1,856[2] .
$$

In terms of transformers:

$$
\rho_{T}^{(N S)}=u_{k}^{-2},
$$

where $u_{k}$ is short-circuit voltage.

In terms of transformers with power being more than $630 \mathrm{kV} \cdot \mathrm{A}$ as well as asynchronous and synchronous electric motors with power being more than $100 \mathrm{~kW}$ with nominal voltage being $6-10 \mathrm{kV}$ without appreciable error, complex impedance $z_{2}$ may be replaced by corresponding inductance $x_{2}$.

Additional voltage losses with inthenet work elements cause additional heating of insulation resulting in its shortened service life.

Relative reduction of insulation service life in terms of voltages asymmetry $\Delta t_{2}^{*}$ is determined according to expression $[2,6]$ :

$$
\Delta t_{n}^{*}=\left\{\begin{array}{l}
0,087 \tau_{1} \frac{\Delta P_{N S}}{\Delta P_{n o m}}-\text { for insulation of } A, E \text { class; } \\
0,069 \tau_{1} \frac{\Delta P_{N S}}{\Delta P_{n o m}}--/ /-B, F, H \text { class. }
\end{array}\right.
$$

Similarly to the previous case, when losses due to additional thermal ageing of insulation are calculated, relative reduction of its service life is performed by corresponding increase in deductions $\Delta C_{p}^{*}$ for electric equipment renovation:

$$
\Delta t_{2}^{*}=\Delta C_{p}^{*} .
$$

Annual losses ( $Z /$ year) stipulated by negativesequence current flowing in $S^{\text {th }}$ type of electric equipment may be calculated according to formula:

$$
Y_{N S}^{(s)}=\beta T^{(s)} \Delta P_{N S}^{s} \cdot 10^{3}+\Delta C_{p}^{*(s)} C_{p}^{*} K^{(s)},
$$

where $\beta$-is cost of $1 \mathrm{~kW} \cdot$ hour of electric energy losses, $z / \mathrm{kW} \cdot$ hour; $T^{(s)}-$ is the number of thousands of hours of $S^{\text {th }}$ type of electric equipment per year, hours. hour/year; $C_{p}^{*(s)}-$ is standardized coefficient of deductions for renovation from capital costs $K^{(s)}$ of $S^{\text {th }}$ type of electric equipment.

While developing expressions for transformers, attention was paid to their 75 percent burden and temperature equalization of nonuniformly loaded phases performed by the transformer oil. When losses due to negative-sequence current flowing in cables are determined, it is possible to neglect the costs of additional losses in cable cords; the loss is defined by the reduction of insulation service life.

Expression for the losses of transformations of valve inverters has been developed basing upon the connection between negative-sequence current and positivesequence current consumed by converters in terms of asymmetric voltage position [2, 7-9]:

$$
I_{2}=0,391 I_{1} K_{2 U} .
$$

Losses (Z/year) stipulated by voltage asymmetry with in the clamps of capacitors are expressed as follows:

$$
\begin{gathered}
Y_{N S}^{(C B)}=\beta T^{(C B)} Q_{n o m}^{C B} K^{(s)} \operatorname{tg} \delta+ \\
+5,7 \frac{C_{p}^{*(C B)} K_{0}^{(K B)} Q_{n o m}^{C B}}{3}\left[K_{2 U}^{2}+2 K_{2 U}^{*} \cos \theta_{L}\right],
\end{gathered}
$$

where $T^{(C B)}$ is the number of thousands of hours of capacitor operations per year.

Using the proposed dependences, mathematical modeling of various levels of energy losses within the electric equipment due to asymmetry and higher harmonics has been performed (Fig.1). Specific feature of the dependences is as follows: taking into consideration the parameters of power system (short circuit power) being of great importance to determine levels of losses at different stages of energy distribution $[3,5,7,10]$. 


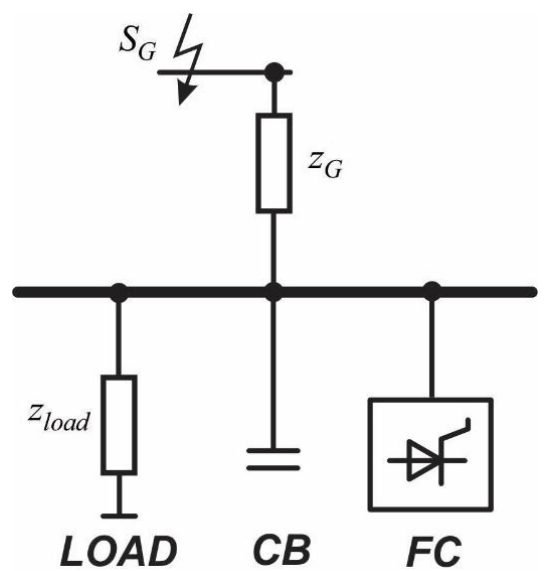

a)

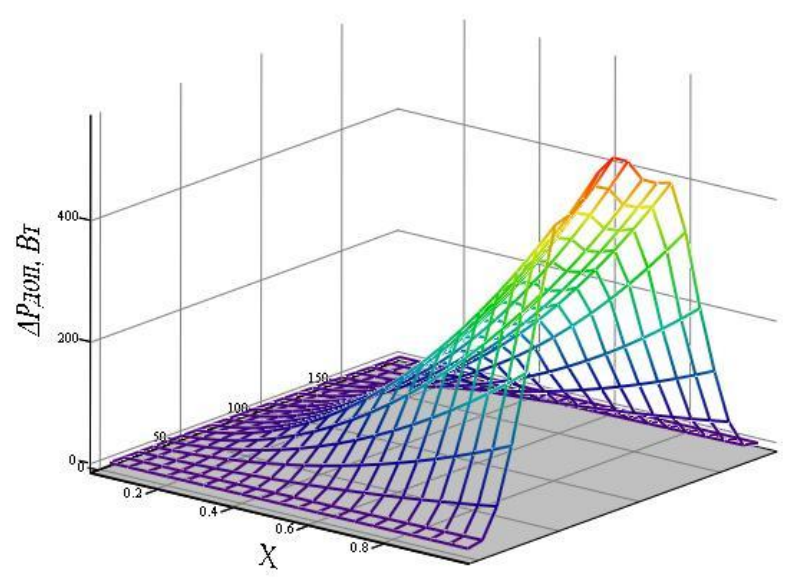

c)

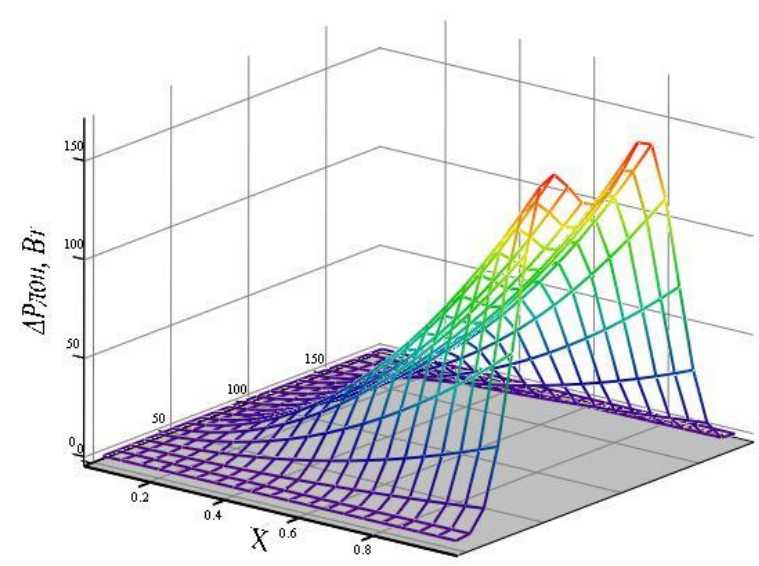

b)

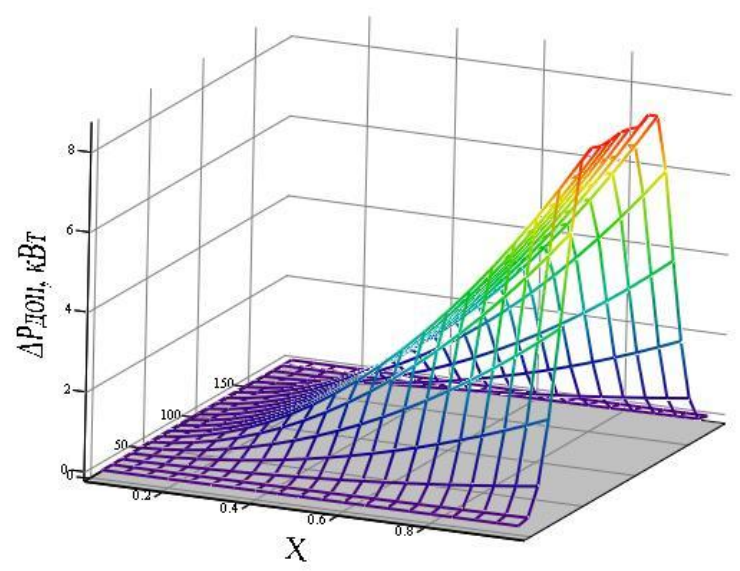

d)

Figure 1 - Dependences of additional power losses within the electric equipment:

a) explaining scheme of electric network substitution;

b) asynchronous motor with the capacity of $15 \mathrm{~kW}$;

c) capacitor unit with the capacity of $600 \mathrm{kvar}$;

d) power transformer with the capacity of $630 \mathrm{kV} \cdot \mathrm{A}$

The represented dependences contain the introduced notion of relative remoteness of $\mathrm{X}$ electric equipment from the point of electromagnetic interference generation. One should understand the following fact: if electrical receiver is powered from the same point as the source of interference, then $X=1$. In terms of considerable remoteness, $X=0$.

When we introduce the assumption on the remoteness of electric receiver from the source of infinite power, then it is substantiated that the depth of switching distortions $\Delta U_{1}$ and, consequently, high harmonic components are determined by following dependence $[1,5]$ :

$$
X=\frac{z_{G}}{z_{G}+z_{\text {load }}},
$$

where $X_{G}$-is impedance of a power network; $X_{\text {load }}$ is load impedance.
CONCLUSIONS. Mathematical modeling of levels of additional losses within the electric equipment in terms of various operating modes of the source of electromagnetic interferences has been performed. Zones with the highest values of power losses (control angles within the zone of $60-120^{\circ}$ ) are represented unambiguously. In this context, it is possible to determine the modes with the most efficient operating parameters of the power supply system being topical in terms of mass implementation of active-adaptive electrical networks.

While modeling power losses with in the electric equipment, use of term "remoteness" (a distance being proportional to the depth of switching over voltages in terms of operation of non-linear source of electromagnetic interferences) has been substantiated. Simultaneous use of the value and parameters of electrical network in the process of modeling makes it possible to determine the zones of efficient operation of electric equipment with the accuracy sufficient for engineering calculations. 


\section{REFERENCES}

1. Pivnyak, G. G., Zhezhelenko, I. V., Papaika, Yu. A. (2016), "Transients in Electric Power Supply Systems": textbook for students of higher educational institutions under the editorship of Academician of National Academy of Sciences of Ukraine Professor G. G. Pivnyak, TTP, Switzerland.

2. Zhezhelenko, I. V., Shidlovskiy, A. K., Pivnyak, G. G., Saenko, Yu. L., Noyberger, N. A. (2012), Elektromagnitna sumistnist spogivachiv [Elektromagnetic compatibility of consumers], Mashinostroenie, Moskow, Russia.

3. Pivnyak, G., Zhezhelenko, I., Papaika, Yu. (2013), "Normalization of voltage quality as the way to ensure energy saving in power supply systems", Energy Efficiensy improvement of geotechnical systems, Taylor\&Francis Group (A Balkema Book), London, UK.

4. Pivnyak, G. G., Zhezhelenko, I. V., Papaika, Yu. A., Lysenko, A. G. (2017), "Interharmonics in power supply systems", Naukovyj visnyk NGU, Vol. 6, pp. 109114.

5. Papaika, Yu., Kosobudzki, G., Lysenko, A. (2017), "Power Quality and Resonances in Power Supply Systems with non-sinusoidal Loads", Advanced engineering forum, Trans Tech Publication, Switzerland, pp. 143-150.

6. Pivnyak, G. G., Rogoza, M. V., Papaika, Yu. A., Lysenko, A. G. (2015), "Traction and energy characte- ristics of no-contact electric mining locomotives with AC current thyristor converters", Tailor \& Francis Group: Power Engineering, Control and Information Technologies in Geotechnical Systems, Leiden, The Netherlands, 2015 annual publication, pp. 1-6.

7. Pivnyak, G. G., Zhezhelenko, I. V., Papaika, Yu. A. (2016), "Estimating economic equivalent of reactive power in the systems of enterprise electric power supply", Naukovyj visnyk NGU, Vol. 5, pp. 62-66.

8. Zhezhelenko, I. V., Shidlovskiy, A. K., Pivnyak, G. G., Sayenko, Yu. L. (2009), Elektromagnitna sumistnist $u$ sistemakh elektropostachannya: pidruchnyk [Electromagnetic compatibility in power supply systems: textbook], Natsionalnyi hirnychiy universytet; Dnipropetrovsk, Ukraine.

9. Intelektualni elektrichni meregi: elementy ta regymy [Intelligent Electric Networks: Elements and Modes] (2016), under the editorship of Academician of National Academy of Sciences of Ukraine Professor O. V. Kyrylenko, Institute of Electrodynamics NAS of Ukraine, Kyiv, Ukraine.

10. Zhezhelenko, I. V., Papaika, Yu. A., Lysenko, A. G. (2017), Otsenochnie metodi opredeleniya ekonomicheskogo ekvivalenta reaktivnoj moshchnosti [Estimation methods for determining the economic equivalent of reactive power], Girnicha elektromekhanika ta avnomatyka, no. 98, pp. 3-6.

\section{ПОТЕРИ ЭНЕРГИИ В ЭЛЕКТРООБОРУДОВАНИИ ПРИ НИЗКОМ КАЧЕСТВЕ НАПРЯЖЕНИЯ}

\section{Ю. А. Папаика, О. Г. Лысенко, М. В. Рогоза, Ю. В. Степаненко, Л. О. Токар}

Национальный технический университет «Днепровская политехника»

просп. Дмитрия Яворницкого, 19, г. Днепр, 49005, Украина.

E-mail: papaika@ukr.net; lysenkoag@ukr.net; rogozam@nmu.org.ua; yuvist@ukr.net; lrstokar@gmail.com

\section{С. Н. Якимец}

Кременчугский национальный университет имени Михаила Остроградского

ул. Первомайская, 20, г. Кременчуг, 39600, Украина. E-mail: ysm_seem@meta.ua

Данная публикация направлена на объединение терминов энергоэффективность и качество электроснабжения. В статье рассмотрены электромагнитная и технологическая составляющие экономического ущерба, обусловленного сниженным качеством электроэнергии. Показаны современные методы определения дополнительных потерь мощности в основном электрооборудовании и убытков от поставок некачественной электроэнергии. Указано, что основные причины снижения качества напряжения в электрических сетях Украины - это массовое внедрение преобразователей частоты и неудовлетворительный контроль качества энергии со стороны энергетических компаний. Полученные зависимости потерь мощности в асинхронных двигателях, конденсаторных установках и силовых трансформаторов с применением научно обоснованного термина «удаленность» источники электромагнитных помех в электрической сети. Результаты исследования позволяют оценивать эффективность электроснабжения в условиях постоянного изменения параметров и неопределенности, является основой создания так называемого «интеллектуального» электроснабжения. Разработанные модели будут положены в основу комплексной методики определения оптимального электроснабжения. Методика может быть применена для систем электроснабжения городов, предприятий и электроэнергетических объединений.

Ключевые слова: качество электрической энергии, потери электроэнергии, силовые трансформаторы, асинхронные двигатели, конденсаторные установки, электрические сети. 